\title{
Promotional Messages on Social Media Marketing for Natural Seeds Jewelry
}

\author{
${ }^{1}$ SANTI SUSANTI, ${ }^{2}$ SUKAESIH, ${ }^{3}$ IWAN KOSWARA \\ ${ }^{1,2,3}$ Faculty of Communication Sciences, Universitas Padjadjaran, Jatinangor, Indonesia \\ correspondence: santi.susanti@unpad.ac.id
}

\begin{abstract}
This study aims to examine the promotional messages in social media marketing for natural Seeds jewelry. This research uses descriptive qualitative methods and data is collected through interviews, observation, documents, and literature review. The object of this study is Bumi Putih Spiritual Jewelry, a brand of handmade jewelry products from natural seeds created by Anthony Imanuel Alexander Sutrisno. Data analysis in this research uses Miles and Huberman's interactive method. The results show that Bumi Putih uses Instagram, Facebook and Twitter integrated for marketing the natural seeds jewelry. Promotional messages conveyed on the three platforms of social media are a combination of verbal and nonverbal messages in the form of text and symbols to influence the audiences' cognitive, affective, and conative. By using social media, Bumi Putih not only marketing the products but also persuade netizens to respect nature and maintain its sustainability to create a harmonious relationship between human and the environment.
\end{abstract}

Keywords: social media marketing, natural seeds jewelry, promotional messages

\section{Introduction}

Social media has become an integral part of people's lives today. It has changed the way humans communicate, including communicating products and attract potential buyers. Social media users increase from year to year. Hootsuite and We Are Social result research, released in January 2019, noted that there were 3.484 billion active social media users around the world, increased $6.1 \%$ from 2018 . It means 45 percents of the 7.676 billion world population spend their activities by interacting on social media. The majority $(93 \%)$ of users access social media through mobile devices.

We Are Social data reported in January 2019 shows the number of internet users in Indonesia reached 150 million or more than a half $(55,9 \%)$ of the population in Indonesia. Approximately, 130 million people are social media active users who spend their time up to three hours 26 minutes on their various gadgets/devices. The most active social media platforms in Indonesia are YouTube $(88 \%)$, WhatsApp (83\%), Facebook $(81 \%)$,
Instagram (80\%), Line (80\%), Twitter (52\%), etc. (Riyanto, 2019).

For the entrepreneurs or a company, this number is an opportunity to promote the products to social media active users. One of them is Bumi Putih Spiritual Jewelry, a brand owned by Anthony Imanuel Alexander Sutrisno, an entrepreneur and artisan who made accessories and jewelry from natural seeds. Bumi Putih Spiritual Jewelry, formed in 2010, applies the eco-friendly jewelry concept as the identity of its fine works made by Anthony from natural seeds knotted with nylon cords into artistic and economic value accessories. Anthony has created many accessories for sale or adopted for himself because of philosophical and historical values associated with him.

Anthony produces natural seeds jewelry because he loves nature to be preserved. Anthony's business is also associated with his efforts to preserve nature.

Bumi Putih Spiritual Jewelry is not a mass product. It made by orders or ideas from Anthony as the creator at Bumi Putih. Anthony

Received: 2020-03-28, Revised: 2020-05-05, Accepted: 2020-06-03. 
uses social media in marketing his work of art, with hopes he can reach a broader market for his products and encourage people to do nature's preservation (Anthony, interview, 8 July 2018).

Research on the use of social media as a marketing channel has conducted by some researchers. Wenday Dwi Novi Kurniawati (2016) from Universitas Muhammadiyah, Surakarta, conducted research on the use of social media Instagram in promoting regional tourism. The results show the success of promotion tourism potentially supported by four components: communicators, messages, media, and communicants. Using Instagram provides many advantages for Grobogan tourism community in promoting the local tourism potential, including facilitating the dissemination of travel information and attracting the attention of users to access the Grobogan Tourism Community (Kurniawati, 2016).

Wenday Dwi Novi Kurniawati's research focuses on efforts to increase the tourism potential by the community. This research focuses on promotional messages in social media for marketing natural seeds jewelry of Bumi Putih Spiritual Jewelry.

The next research is Komunikasi Pemasaran Usaha Kuliner dalam Menghadapi Persaingan (Culinary Business Marketing Communication in Facing Competition) conducted by Akbar Prayogo and Adolfo Eko Setyanto from Universitas Sebelas Maret, Surakarta. The results show that Gerobak Cokelat Café carries out marketing activities such as sales promotion, advertising, publicity, public relations, and word of mouth. From this activity, the most effective marketing communication activities are the word of mouth and Twitter while the marketing communication activities that cannot penetrate consumers are electronic advertising media (Prayogo \& Setyanto, 2015).

Marketing communication defines as strategies, tactics, and activities in sending the desired marketing message to the intended target market, regardless of using the media (Tsikirayi, Muchenje, \& Katsidzira, 2013). Marketing communication is used to inform, influence, and increase customers directly and indirectly. Marketing communication will run well if the message content can be understood easily.

The primary purpose of marketing communication is conveying information to the target audiences to change their attitude cognitively, affectively, and conatively. Terence A. Shimp explains marketing communication has the objectives as follows: (1) Generating a desire for a product; (2) Brand Awareness; (3) Intention; (4) Facilitating the Purchases (Shimp, 2014).

One of marketing communication element to introduce and convince audiences to put their attention to the products offered is promotion; an effort to attract buyers' attention through communication techniques.

Promotion is an important thing to do in developing business, to increase brand awareness of products in the community, or to maintain the existence of the products in the market. Promotion according to Boone and Kurtz is the process of disseminating information, persuading, and convince a purchasing decision. Promotional activities are part of the marketing strategy needed by the business, both small and medium-sized businesses (Boone \& Kurtz, 2005).

In this study, the promotion carried out is to introduce jewelry products and natural accessories from seeds made by Bumi Putih Spiritual Jewelry. The channel used for product promotion activities is social media, which is an internet-based application that can be used as a medium for delivering information. David Meerman Scott defines social media as follow:

"Social media provides the way people share ideas, content, thoughts, , and relationship online. Social media differ from so called "mainstream media" in that anyone can create, comment on, and add to social media content. Social media can take the form of text, audio, video, maps, and communities" (Scott, 2010).

The presence of social media provides flexibility for the public to share the information. Social media makes users easy to participate, share, and create informative content on blogs, social networks, wikis, forums, and other virtual worlds. Blogs, social networks, and wikis are perhaps the most common forms of social media used by people around the world (Ardianto, 2011).

Nowadays, social media comprises thousands of platforms; some of them are more popular than others, but each of them has their own audience and users as each serves a different type of person. For instance, Instagram is for those who communicate 
better through pictures, Twitter is for those who communicate better by the means of words (Harry \& Kuehn, 2019).

Various types of social media can be an alternative for digital promotion. Social media that are often used as promotional media include Facebook, Twitter, and Instagram.

The use of social media by the Indonesian people increasingly diverse. Not only the activities of making friends and socializing, but also to run business, especially to promote the products. Ads are changing from the traditional way where the company spends high cost for making ads to customer participation in social media (Purwaningwulan, Suryana, Wahyudin \& Dida, 2019). Anthony uses social media to communicate the information of his products. Facebook, Twitter, and Instagram are chosen to be mediums to communicate the messages of Anthony's work of art.

Social media marketing is defined as the process that empowers individuals to promote their websites, products, or services through online social channels and tap into a much larger community that may not have been available via traditional channels (Weinberg, 2009). As an effective use of time and resources, social media marketing gives companies better communication grounds with consumers to build brand loyalty beyond traditional methods (Jackson, 2011; Akhtar, 2011).

Businesses can promote products and services, provide instant support, and/ or create an online community of brand enthusiasts through all forms of social media such as social networking sites, content communities, virtual worlds, blogs, microblogging sites, online gaming sites, social bookmarking, news sites, forums, and more (Zarella, 2010; Kaplan \& Haenlein, 2010; Weinberg, 2009).

Social media marketing is different than traditional methods of marketing. It requires special attention and strategy building to achieve brand image and loyalty. Social media marketing is related to relationship marketing where the firms need to shift from "trying to sell" to "making connections" with the consumers (Gordhamer, 2009).

Social media marketing is also more sincere in its communication with the consumers, trying to show what the brand is rather than trying to control its image. Finally, today's customers are more powerful and busy, therefore, companies should be reachable and available in every social media communication channel such as Facebook, Twitter, Blogs, or Forums at any time (Gordhamer, 2009).

Anthony with his social media is trying to make a connection with his customers rather than trying to sell his product to the customers directly. This research takes place at Bumi Putih Art Gallery, Jalan Cikutra V No. 7 , Bandung. This place is a place for making accessories from the beginning until they become ready-made accessories.

This study uses Max Weber's Social Action Theory which defines actions or behavior as any meaningful actions or experiences that are realized by a person or group of people who appear in the form of daily life patterns (Schutz, 1967). For Weber, social action is the act of someone that has a subjective meaning for himself and directed to the actions of others (Ritzer, 1975) Social action involves interpretation, thinking processes, and intentional. Social actions are carried out for a particular purpose.

Weber distinguishes human social action into four types: (1) rational actions of purpose; (2) rational actions of values, (3) effective actions; and (4) traditional actions. In rational actions of purpose, the actor assesses and determines the goal and does the action to achieve other goals. In rational action of values, the actor chooses how to determine the desired goals. Affective actions are dominated by emotions or pretension, which makes the actor's actions difficult to understand. Traditional actions are actions based on habits in doing something in the past. Weber explains that the affective actions and traditional actions are more than just automatic acts of response to external stimuli so that they can be understood as meaningless. However, at certain times, the two actions can turn into meaningful and fully understood actions (Wadiyo, 2007).

Every action Anthony takes in marketing his product is a conscious behavior carried out through a thinking process based on his interactions with the community in daily life. There are motives, values, and goals in each individual to interpret physical behaviors that have subjective meaning in the environment in which the informant domiciled.

\section{Research Methodology}

This study uses descriptive qualitative methods to make a systematic, factual, 
and accurate description or description of the facts, traits, and relationships between the investigated phenomena. "Descriptive research describes situations or events, does not seek or explain relationships, does not test hypotheses or make predictions". The emphasis of the descriptive method is observation and natural situations. The researcher acts as an observer. He/she only make a category of actors/doers, observed symptoms, and recorded them in an observation book (Rakhmat, 2002: p. 24-25).

In this study, the observation is conducted on the subjects' behavior during the interview and when the informants are carrying out activities related to the processing of natural seeds into accessories. We also observe the social media accounts to determine the activities and forms of communication carried out to market the accessories product.

We collect the data through in-depth interviews, observation, and documentation studies. We conduct the interviews to get the information about the views, events, activities, opinions, and feelings of the resource persons regarding the use of Instagram in promoting the seeds jewelry by Bumi Putih Spiritual Jewelry. Furthermore, the interviews are conducted to get accurate data and data sources.

We conduct direct observation on the seeds jewelry making process and Anthony's Instagram account in promoting the work he produces. The documentation study is conducted to enrich the theoretical foundation and sharpen the analysis related to this research topic. We conducted this research in Bandung with Anthony Sutrisno as the informant. He is the owner and the artist of Bumi Putih Spiritual Jewelry who running the social media of his products by himself. We carry out data processing and analysis before and after the data collection period in the form of data reduction, data presentation, and conclusion.

\section{Results and Discussion \\ Bumi Putih Spiritual Jewelry: In Harmony with Nature}

Anthony chose Bumi Putih as the identity of his work, which means creating works without exploiting nature, but taken what needed and taking care of the earth. Caring for the Earth, studying on the Earth, and working for the Earth are the slogans that mark how Bumi Putih's works categorized as eco-friendly work of art.

For Anthony, as a fellow living creature, maintaining harmony with nature means mutual respect between nature and humans, including aspects of honesty. It applies in the work and treats the results of his work.

Anthony explains the process of his work is a part of interpreting seeds philosophy and based on his gratitude for the gift of the Creator through the seeds he assembled. "It's like contemplating. So, that's why I call it spiritual jewelry."

\section{Social Media Marketing of Bumi Putih Spiritual Jewelry}

Social media is a new media paradigm within the scope of the marketing industry. Weber also mentioned that conventional media such as TV, radio, and newspapers have so far only facilitated one-way communication while social media communication is two-way so that it allows every user to make publications and contribute through online conversation (Zarella, 2010).

Social media has the following characters: (1) participation, which encourages feedback and contributions from everyone expected; (2) openness, open social media for every participation through various communication channels; (3) conversation, which allows conversation between users; (4) the community can provide information about issues/interests; and (5) connectivity, the media provides connectivity among users through various linking facilities in the website (Gustam, 2015).

Through social media, product owners can convey information about their products or services. In this study, the types of social media used are Facebook, Twitter and Instagram. There is a correlation between the use of Instagram and visiting interest followers (Ahmadi, D. \& Adzhani, 2019).

\section{Promotional Messages of Bumi Putih Spiritual Jewelry on Social Media}

The presence of social media has changed the role of consumers in buying and selling transactions from originally passive targets to the active recipients, from designing product models to promotional messages. The interactive concept offered by social media makes everything possible (Hanna, Rohm, \& Crittenden, 2011). 
Promotion is an attempt to persuade consumers to use the products or services offered by producers. Promotion must be carried out during the production and distribution process. Promotion includes all ways to inform products and services to the consumers and how to market and sell them (Tracy, 2004).

Promotional content is persuasive communication messages addressed to the public or consumers to introduce products/ services. The intended message is a set of verbal and/or nonverbal symbols that represent the purpose of the sender. The message comprises meaning, symbols used to represent meaning, and the form or organization of messages (Mulyana, 2000).

The message contains information conveyed by the sender of the message (marketer) to the public (consumers). In marketing, marketers can present messages to attract consumers. Messages that packaged interestingly will be easier to remember.

There are two types of communication: verbal and nonverbal communication. Verbal communication is one type of communication carried out to convey business information to other parties/ consumers both in writing and oral. Effective communication activities depend on the skills of communicators and communicants in understanding the messages. Communicators can use written and oral forms of communication to send messages. Meanwhile, to receive messages, the communicant can use hearing and reading (Purwanto, 2006).

Nonverbal messages are messages delivered using non- language. Mulyana defines:

\begin{abstract}
"Nonverbal communication includes all stimuli (except verbal stimuli) in a communication setting, which is produced by individuals, used by individuals, and has potential value for every communication actor" (Mulyana, 2000).

The phrase "a picture speaks a thousand words" can be interpreted as an utterance which shows how easier it is to show something with a picture than to explain it in words. This is what Anthony chooses to upload his work on Instagram in the context of promotion, as well as luring visitors to be interested to visit his account to adopt his work.
\end{abstract}

The selection of Instagram as one of the promotional media for Anthony's works is part of the communication strategies used to reach a broader audience than the promotion carried out offline directly through exhibitions, environmental-themed events, and others. In addition, in terms of management, Anthony can do it himself as the Instagram account owner (@tonyputih). Even in terms of costs, the promotion through Instagram does not require a large fee; the most important is the availability of the internet to operate Instagram. Promotion through Instagram is expected to expand the product performance towards potential consumers.

Instagram is social media for sharing pictures, photos, and short videos. Its presence since October 2010 provides space for users to share, interact, and present themselves, and form the opinions of their audiences through photos and videos accompanied by caption and comment column.

Instagram has the ability as a means for online photography. As it develops, this media is used to promote goods and services by individuals and companies. Instagram has turned into a fast and accurate information provider and a means for promotion, marketing, and distribution of goods and services (Hoffman \& Novak; Doolin et al.; \& Sweeney in Fatanti \& Suyadnya, 2015). According to Abbott (in Ting, Ming, de Run, \& Choo, 2015), Instagram is an effective medium for increasing business opportunities and self-existence by creating an identity.

Even though the space provided is not large for writing caption, the image is believed to say more than words. Besides being able to display images, this interactive designed application can also make the account owners and visitors interact with each other. Instagram allows individuals to share their pictures and videos through their smartphones.

Instagram has excelled as an effective communication and marketing tool for displaying products with visual descriptions. There are 200 million registered users and 20 billion photos have been posted with an average of 60 million photos are uploaded per day. From these results, Instagram is considered as the most popular social media for sharing photos and it can also interact with friends, other people, and brands around the world (Ara, Paulo, \& Corr ${ }^{\wedge}$, 2014).

Anthony chooses Instagram as the primary channel for marketing his works 
because Anthony's creations and accessories are visible works so that the audience will know the products made by Bumi Putih Spiritual Jewelry. Each post is a combination of images and text that explains the specifications of the work produced.

The features on Instagram include sharing and hashtags. The sharing facility allows account owners to share content among Instagram users. Hashtag facility serves to mark photos uploaded by, to make it easier for other users to find them. A hashtag can also facilitate the users to help distribute the photos to other Instagram users. Besides, the hashtag also functions as a grouping of content, content search, and product promotion (Sheldon and Bryant, 2016). These functions show that Instagram has power as a medium that can be used for contemporary promotion (Fatanti \& Suyadnya, 2015).

From our observations, the material uploaded in Instagram is synergized with the same posts on Facebook and Twitter. It interrelates and reinforces the three platforms since they often display the same images. Anthony often uses Instagram for promoting his works because there are more photos and pictures displayed on Instagram than on Facebook and Twitter. Here are samples of the interrelation of those three social media accounts in promoting Anthony's jewelry.

Q Search Twitter
bumi putih @putih07 · Feb 8
Available to be adopted of
Adjustable rudraksha bracelet. $16-20 \mathrm{~cm}$.
Made with:
Natural rudraksha 5 mukhis ;
- stress relief.
- enhances blood circulation system.
- good for chakra cleansing.
Cassia wooden... instagram.com/p/B8Sy 2 xdlUiX/...

Figure 1. Anthony promotes his work on Twitter and posted links to visually display products on Instagram

(source: Twitter account, @putih07)

In figure 1 , we can see the connection between Anthony Twitter account, @putih07, and his Instagram account in promoting his craft products. The appearance of Anthony's link on his Twitter can be seen figure 2 .

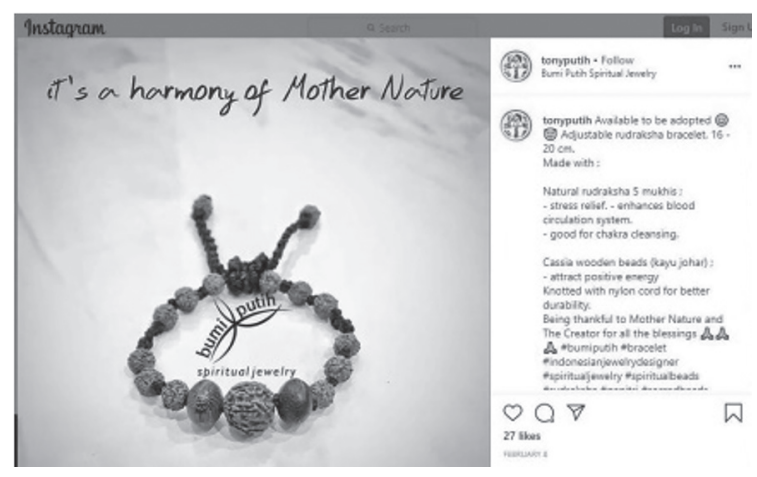

Figure 2. Product promotions on Anthony's Instagram account, @tonyputih, which the link displayed on his Twitter account

(source@tonyputih)

Figure 2 shows the promotion of a natural seeds bracelet made by Anthony, the link of which posted on Twitter. This shows a synergy between two different social media accounts in promoting one product. Anthony's action interpreted as an attempt to expand the product's market share, specifically to people who appreciate his works.

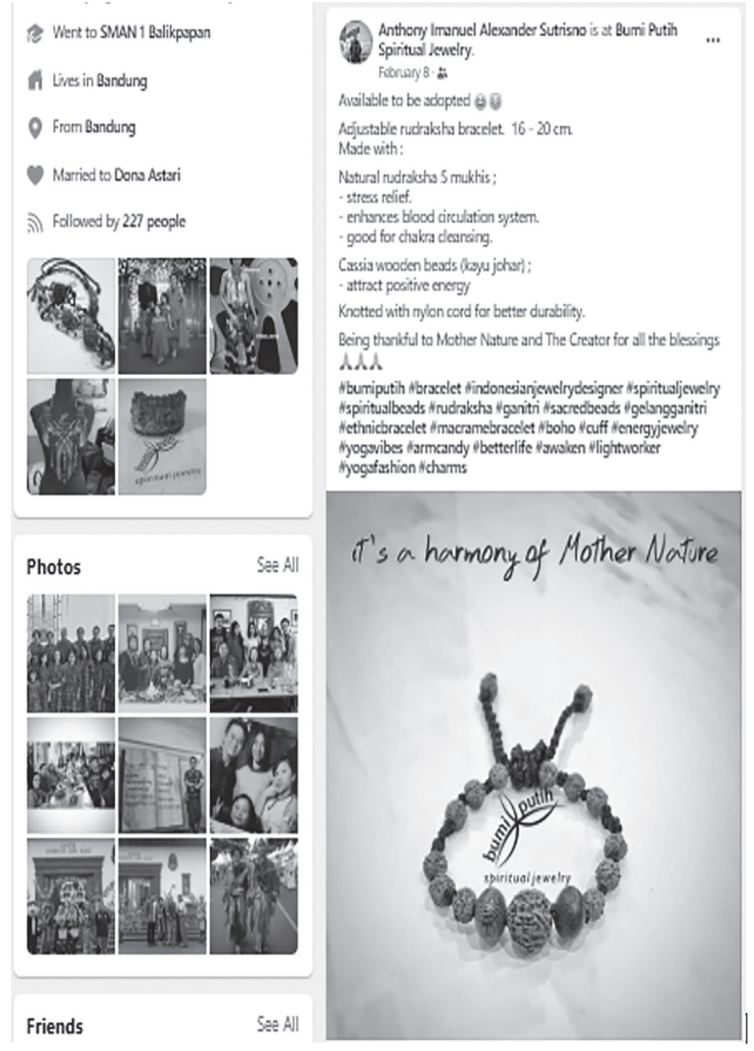

Figure 3. Promotion of the same work on Anthony Imanuel Alexander Sutrisno's Facebook account. This content displays on February 8, 2020.

(source: Anthony's Facebook account) 
Figures 1, 2 and 3 show the integration of social media marketing throughout Anthony's social media accounts on Twitter, Instagram, and Facebook to promote his craft products. The same product displayed on Anthony's three social media accounts tailored to the character of each media he uses.

In every picture being uploaded, Anthony always writes a caption or describes the work he has done. It contains information about the material being used to produce the work. In addition, Anthony also includes a hashtag in each upload. The hashtag acts as a keyword to search for Anthony's posts on Instagram. The hashtags are written more than one to make it easier for the netizens to find the uploaded material they are looking for.

Anthony chooses many ways to promote his work through Instagram. He displays the product branding and personal branding. Product branding is a strategy that defines a unique set of marketing elements to differentiate a given product. It is an activity that defines the way the product's image is communicated to its customers.

In product branding, Anthony displays various results of his work of necklaces, bracelets, neckties, and others in the form of fixed and raw materials, and also the process carried out in producing natural seed accessories.

According to Nasrullah, there are six categories of social media classifications: 1 ) Social networking media that allows its users to engage a social relationship in the virtual world and the consequences of those social relationships, such as the formulation of values, morals, and ethics, 2) Online journal (blog), a social media that allows its users to upload their daily activities, comment on each other, and share links from another web, information, and etc., 3) Simple online journal (microblogging), a social media that facilitates its users to write and publish their activities or opinions within 140 characters, 4) Media sharing, a social media that facilitates its users to share media, from documents (files), video, audio, images, etc., 5) Social bookmarking, a social media that works to organize, store, manage, and search for certain information or news online, 6) Media shared content or wiki, a media or website that allows its users to collaborate to build content together (Nasrullah, 2017).

Based on Nasrullah's explanation, the media used by Anthony is a combination of social networking, online journal, microblogging, and media sharing. Facebook, Twitter, and Instagram used by Anthony have a mutual support position in marketing and expanding the target market of accessories and natural jewelry produced by Anthony.

In figure 4, Anthony shows his appreciation of seeds as part of nature, which is as valuable as diamonds. Through this picture, Anthony invites his followers to care about seeds as part of the harmony of mother nature. This behavior is one of the social actions that reinforce Anthony's positioning as an individual who works and preserving nature.

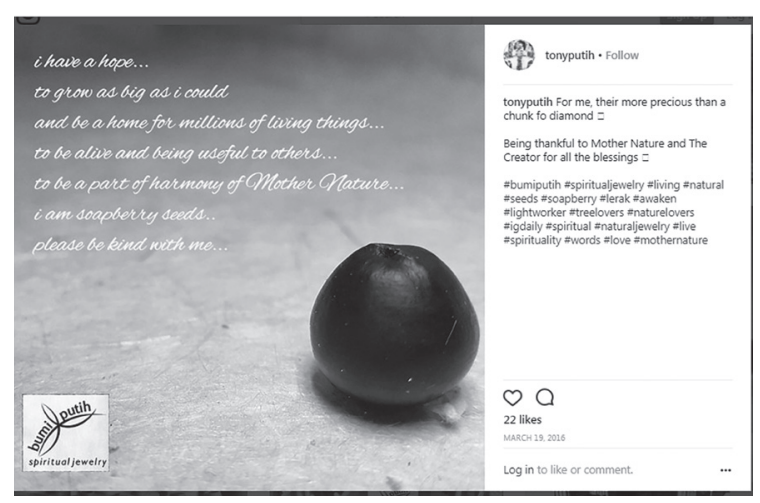

Figure 4. One of Anthony's appreciation of seeds expressed in picture and words (source@tonyputih)

\section{Personal Branding: Strengthening Product Brand}

To strengthen the product promotion, Anthony conducted personal branding for his work of art. Anthony, who is a fan of accessories, uses parts of his body, hands, and neck as a walking promotion of the work he intentionally made.

Anthony's appearance wearing accessories in social media, according to him, is a part of his daily life. Aside from being a symbol of his expertise, his appearance is an effort to give awareness to the audience, showing how the seeds have a meaning more than just plants and the work it produces has a value that is not different from metal jewelry produced by industry.

For Anthony, his work of art is gratitude for the blessings of nature and maintaining a harmonious relationship between humans and nature.

In figure 5, we can see Anthony is stringing seeds with nylon thread into jewelry. 
This image is part of personal branding that Anthony built as an artist at Bumi Putih Spiritual Jewelry by demonstrating his ability to make jewelry from natural seeds. This image is one of Anthony's photograph collections on Instagram @tonyputih that shows the process of producing natural seeds jewelry. These images show an ongoing process carried out by Anthony to build his personal brand as the creator of natural seeds jewelry displayed on his social media. This explanation is in accordance with the description given by Open Colleges, "Personal branding is an ongoing process to build an image or impression that is determined in the minds of others about an individual. It is the association people have to a name." (www. opencolleges.edu.au, n.d.).

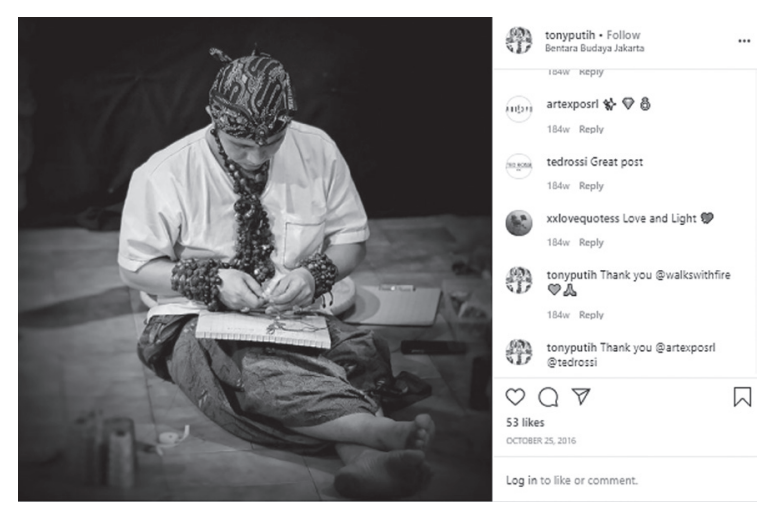

Figure 5. Anthony makes jewelry by stringing natural seeds with nylon thread using rigging techniques. The activity in this picture is one of Anthony's personal branding on his Instagram account.

(source: Instagram @tonyputih)

Anthony's behavior through social media to create product brands and personal brands is a form of social action as conveyed by Weber. The use of social media is done consciously and rationally with certain purposes that Anthony wants to convey to the public. For Anthony, his behavior has a subjective meaning as an effort to instill confidence in the public about who he is and the quality of the products he produces.

With his simultaneous efforts to display the work, personality, and comments by individuals who adopted his works, Anthony hopes the brand image and personal image he wants to create are formed in the minds of the netizens so that the tagline he writes in each photo's captions is a series of sentences that have meaning and imprint in the mindset of the netizens. Thus, the effort to build awareness to love nature and to be grateful for God's blessings has been conveyed, at least to netizen's knowledge; and the proper step is to take action to respect nature and preserve it.

\section{Accessories as a Social Action}

Human action is considered as a form of social action when the action has a subjective meaning for himself/herself and the action is aimed at the others with an orientation to the actions of others. Whatever the form of the behavior is, as long as it has the intention to be addressed to others, even if it is only inside the heart, it can be categorized as a social act.

Art can be categorized as a form of social action, because in art, the work produced is not just autonomous human self-expression which is based on the sense of aesthetics, as well as delivering messages to the audience to achieve certain goals. As conveyed by Effendy (in Wadiyo, 2007), art is the social action of a person or group of people in relation to the delivery of ideas and messages to others. Through work, an art creator asks for a response from others to the art being created or presented.

Likewise, Anthony Sutrisno works to produce jewelry from natural seeds where it is one form of the art carried out by Anthony to channel his artistic desires. It is also an appreciation for the local wisdom of Sundanese culture, in which Anthony's understanding is very close to nature. In making his work, there are certain values that Anthony wants to convey to the public, including the value of caring to preserve the environment to be sustainable, and the value of mutual respect for the existence of seeds as fellow creatures of God that must be respected and not exploited in fulfilling the human needs.

In addition, through the work he produces, Anthony has one goal that is to build people's awareness to respect nature and its surroundings, especially seeds/grains. Anthony hopes that by valuing seeds, people indirectly value fellow living beings. Thus, the harmony of human relations and nature can be realized.

\section{Conclusions}

The presence of social media influences the way humans communicate. Various social media with their respective characteristics are 
used by humans to communicate according to their desires and interests. Anthony uses three social media platforms: Facebook, Twitter, and Instagram. Through these platforms, Anthony promotes products in the form of verbal and non-verbal messages, text, images, and symbols represented in product branding and personal branding.

Instagram's presence as a social media that displays short photos and videos as the main communication media is well utilized by Anthony Imanuel Alexander Sutrisno to promote his work of accessories made from natural seeds.

As part of his efforts to instill awareness to netizens about the philosophy of seeds as a source of life, in every picture of his product on social media, Anthony always displays a tagline "It's a Harmony of Mother Nature" and "Being thankful to Mother Nature and The Creators for All the Blessings" in every caption of the work posted on his Instagram.

Referring to Weber's social action theory, Anthony's behavior in creating and promoting the results of his work can be categorized into rational acts of purpose and rational actions of values. Based on the rational purpose of action, Anthony's behavior in his work is driven by the motivation and the aim of building public awareness to respect seeds as part of the nature that must be preserved because they are also living creatures created by God to live in harmony with humans.

\section{References}

Ahmadi, D., \& Adzhani, A. V. (2019). The use Instagram with visiting interest: The correlation between the use @ littlecollins.bdg Instagram with visiting interest. Journal of Physics: Conference Series, 1375(1), 1-6. https://doi. org/10.1088/1742-6596/1375/1/012055

Akhtar, S. (2011). Social Media and Brand Loyalty. Retrieved December 18, 2019, from http://www.socialtrakr.com/2011/07/12/ social-media-and brand-loyalty

Ara, C. S., Paulo, L., \& Corr ${ }^{\wedge}$, D. (2014). It is Not Just a Picture : Revealing Some User Practices in Instagram. (January 2016), 19-23.

https://doi.org/10.1109/LAWeb.2014.12

Ardianto, E. (2011). Handbook of Public Relations. Bandung: Simbiosa Rekatama Media.
Boone, L. E., \& Kurtz, D. L. (2005). Contemporary Marketing. Ohio: Thomson South-Western.

Fatanti, M. N., \& Suyadnya, I. W. (2015). Beyond User Gaze : How Instagram Creates Tourism Destination Brand? 211(September), 1089-1095. https://doi. org/10.1016/j.sbspro.2015.11.145

Gordhamer, S. (2009). 4 Ways Social Media is Changing Business. Retrieved January 2, 2020, from https://mashable. com/2009/09/22/social-media-business/

Gustam, R. R. (2015). Karakteristik Media Sosial dalam Membentuk Budaya Populer Korean Pop di Kalangan Komunitas Samarinda dan Balikpapan. EJournal IImu Komunikasi, 3(2), 224-242. Retrieved from ejournal.ilkom.fisip-unmul.ac.id

Hanna, R., Rohm, A., \& Crittenden, V. L. (2011). We ' re all connected : The power of the social media ecosystem. Business Horizons, 54(3), 265-273. https://doi. org/10.1016/j.bushor.2011.01.007

Harry, S., \& Kuehn, K. (2019). What's A Personal Brand and Why Do You Need One? Retrieved January 19, 2020, from https://www.workitdaily.com/what-is-apersonal-brand

Jackson, N. (2011). Infographic: Using Social Media to Build Brand Loyalty. Retrieved from http://www.theatlantic. com/technology/archive/2011/07/ infographic-using-social-media-to-buildbrand-loyalty/241701/

Kaplan, A. M., \& Haenlein, M. (2010). Users of the World, Unite! The Challenges and Opportunities of Social Media. Business Horizons, 53(1), 59-68. https://doi. org/10.1016/j.bushor.2009.09.003

Kurniawati, W. D. N. (2016). Pemanfaatan Instagram oleh Komunitas Wisata Grobogan dalam Mempromosikan Potensi Pariwisata Daerah. Komuniti, VIII(2), 127-143.

https://doi.org/https://doi.org/10.23917/ komuniti.v8i5. 2943

Mulyana, D. (2000). IImu Komunikasi: Suatu Pengantar. Bandung: Remaja Rosdakarya.

Nasrullah, R. (2017). Media Sosial: Perspektif Komunikasi, Budaya dan Sosioteknologi. Bandung: Remaja Rosdakarya.

Prayogo, A., \& Setyanto, A. E. (2015). Komunikasi Pemasaran Usaha Kuliner dalam Menghadapi Persaingan (Studi Deskriptif Kualitatif Kegiatan Komunikasi Pemasaran "Gerobak Cokelat" dalam Menghadapi Persaingan di Kota Solo. Jurnal Komunikasi Massa, 1. Retrieved from https://www.jurnalkommas.com/ 
docs/JURNAL \% 20KOMUNIKASI $\% 20$ AKBAR\%20PRAYOGO\%20D0210007.pdf

Purwaningwulan, M. M., Suryana, A., Wahyudin, U., \& Dida, S. (2019). The Existence of Social Media as a Promotional Media in the Hijab Image Revolution in Indonesia. Library Philosophy and Practice (e-Journal), 2278. Retrieved from

http://journals.ums.ac.id/index.php/ komuniti/article/view/2943/2443

Purwanto, J. (2006). Komunikasi Bisnis. Jakarta: Erlangga.

Rakhmat, J. (2002). Metode Penelitian Komunikasi. Bandung: PT. Remaja Rosdakarya.

Ritzer, G. (1975). Sociology: A Multiple Paradigm Science. Boston: Allyn and Bacon.

Riyanto, A. D. (2019). Hootsuite (We are Social): Indonesia Digital Report 2019. Retrieved January 21, 2020, from https://andi.link/hootsuite-we-are-socialindonesian-digital-report-2019

Schutz, A. (1967). The Phenomenology of Social World. Translated by George Walsh and Frederick Lehnert. Illinois: Northwestern University Press.

Scott, D. M. (2010). The Rules of Marketing and PR: How to Use Social Media, Blogs, News Releases, Online Video, and Viral Marketing to Reach Buyers Directly (2nd ed.). New Jersey.

Sheldon, P., \& Bryant, K. (2016). Instagram: Motives for its use and relationship to narcissism and contextual age. Computers in Human Behavior, 58(May), 89-97. http://doi.org/10.1016/j. chb.2015.12.059

Shimp, T. A. (2014). Komunikasi Pemasaran Terpadu dalam Periklanan dan Promosi. Jakarta: Salemba Empat.

Ting, H., Ming, W. W. P., de Run, E. C., \& Choo, S. L. Y. (2015). Beliefs about the Use of Instagram : An Exploratory Study. International Journal of Business and Innovation, 2(2), 15-31.

Tracy, B. (2004). The 7 P's of Marketing. Retrieved December 16, 2019, from https: //www.entrepreneur.com/ article/70824

Tsikirayi, C. M. R., Muchenje, B., \& Katsidzira, Z. (2013). Impact of integrated marketing communications mix (IMCM) in small to medium enterprises (SMEs) in Zimbabwe as a marketing tool. Research in Business and Economic Journal, 7(Imcm), 1-12.

Wadiyo. (2007). Berkesenian: Tindakan Sosial Menurut Max Weber. Imajinasi, 3(2).

Weinberg. (2009). The New Community Rules: Marketing on the Social Web (1st ed.). California: O'Reilly.

www.opencolleges.edu.au. (n.d.). The Complete Guide To Personal Branding. Retrieved January 21, 2020, from https:// www.opencolleges.edu.au/careers/ personal-branding-guide.

Zarella, D. (2010). The Social Media Marketing Book. Canada: O'Reilly Media Inc. 